\title{
MedChemComm
}

RESEARCH ARTICLE
View Article Online

View Journal | View Issue

\section{Demonstration of the dynamic mass redistribution label-free technology as a useful cell-based pharmacological assay for endogenously expressed $\mathrm{GABA}_{\mathrm{A}}$ receptors $\dagger$}

Cite this: Med. Chem. Commun., 2016, 7, 426

Received 1st October 2015, Accepted 17th November 2015

DOI: $10.1039 / \mathrm{c} 5 \mathrm{md} 00442 \mathrm{j}$

www.rsc.org/medchemcomm

\author{
Anders B. Klein, Mia Nittegaard-Nielsen, Julie T. Christensen, Anas Al-Khawaja and \\ Petrine Wellendorph*
}

\begin{abstract}
Within the continuous quest for the discovery of pharmacologically interesting compounds, the development of new and superior drug screening assays is desired. In recent years, the use of label-free techniques has paved the way for an alternative high-throughput screening method. An example is the Epic® opticalbased biosensor that relies on dynamic mass redistribution (DMR) for detection. So far, DMR assays have been mostly used to study G protein-coupled receptor (GPCR) pharmacology. Here, we demonstrate the utility of this assay for investigating ligand-gated ion channel receptors. Using the immortalized IMR-32 neuroblastoma cell line, which expresses relatively high levels of several endogenous $\mathrm{GABA}_{\mathrm{A}}$ receptor subunits, we show that GABA produces concentration-dependent cellular responses that can be measured and quantified in real-time. With the aid of the $G A B A_{A}$ receptor-specific agonist muscimol and the selective antagonists gabazine and bicuculline, we confirm that the data corresponds to that of a $G A B A_{A}$ receptor. Based on quantitative real-time PCR measurements, the subunits $\alpha_{3}, \alpha_{5}, \beta_{3}$ and $\theta$ are the most likely candidates for integration into functional receptors. Our demonstration that label-free methods such as the Epic technology can be used to characterize endogenous GABA receptors in the IMR-32 cell line is exemplary for the superfamily of ligand-gated ion channel receptors, and holds interesting perspectives in relation to identifying novel mechanisms of action.
\end{abstract}

\section{Introduction}

$\gamma$-Aminobutyric acid type $\mathrm{A}\left(\mathrm{GABA}_{\mathrm{A}}\right)$ receptors in the mammalian brain are pentameric ligand-gated ion channels with an impressive heterogeneity. Due to the existence of 19 different subunits, a variety of receptors with distinct pharmacology and anatomical localization exists. ${ }^{1}$ The receptors are important drug targets in the CNS. They are involved in anxiety, anaesthesia and sleep, and mediate fast synaptic transmission that is mainly inhibitory by nature. ${ }^{2,3}$ Traditionally, $\mathrm{GABA}_{\mathrm{A}}$ receptor pharmacology research has been performed using electrophysiology and often in Xenopus laevis oocytes or mammalian cells overexpressing recombinant $\mathrm{GABA}_{\mathrm{A}}$ receptor subtypes. $^{4}$ Whereas such measurements provide detailed knowledge about kinetics and cooperativity, it is a labour-

Department of Drug Design and Pharmacology, Faculty of Health and Medical Sciences, University of Copenhagen, Fruebjergvej 3, DK-2100 Copenhagen, Denmark.E-mail: pw@sund.ku.dk

$\dagger$ Electronic supplementary information (ESI) available. See DOI: 10.1039/ c5md00442j intensive and low-throughput technique when it comes to compound screening. Furthermore, it fails to give information about the downstream cellular pathways linked to ion channel activation. This has warranted a need for new pharmacological assays to perform reliable and high-throughput drug discovery for $\mathrm{GABA}_{\mathrm{A}}$ receptor ligands. The introduction of label-free cell-based assays provides an unresolved potential for finding new $\mathrm{GABA}_{\mathrm{A}}$ receptor ligands in a fast and reliable manner and using a holistic readout of cell function. In the current study, we specifically set out to investigate whether label-free cell-based assay using the Epic instrument measuring DMR can be reliably used to study endogenous $\mathrm{GABA}_{\mathrm{A}}$ receptor pharmacology in the immortalized human neuroblastoma cell line IMR-32.

As the name infers, label-free assays provide a highly sensitive means to evaluate live cellular responses to ligands in intact cells without addition of an exogenous label. One of the current-generation label-free platforms is the Epic ${ }^{\circledR}$ system developed by Corning Inc., which is based on optical biosensors, but other instruments or biosensors, such as electrical impedance, can also be used for label-free assays. ${ }^{5}$ In this 
assay, multiwell microplates (384 or 96-well), with optical sensors integrated into the bottom, are used to monitor the translocation of cellular mass in response to ligand application. This cellular response is referred to as dynamic mass redistribution (DMR). ${ }^{6,7}$ Most studies on DMR measurements have been performed with $G$ protein-coupled receptors (GPCRs) using both recombinant systems and endogenous models, typically with the aim of framing the signaling pathways of these, ${ }^{7-11}$ but have also been applied for studying protein-protein interactions with GPCRs, e.g. potassium channels. $^{12}$

Here, we demonstrate the utility of the DMR technology using the Epic instrument to successfully measure pharmacological responses from $\mathrm{GABA}_{\mathrm{A}}$ receptors endogenously expressed in the IMR-32 neuroblastoma cell line.

\section{Experimental procedures}

\subsection{Chemical compounds}

$\gamma$-Aminobutyric acid (GABA), gabazine (SR 95531) hydrobromide, bicuculline methbromide and phorbol 12-myristate 13-acetate (PMA) were purchased from Sigma-Aldrich (St. Louis, MO, USA), $(R, S)$-baclofen was from Abcam Biochemicals (Cambridge, UK), 4,5,6,7-tetrahydroisoxazolo[5,4-c]pyridin3-ol (THIP) was a gift from H. Lundbeck A/S, and CGP36742 was a gift from Dr. Wolfgang Froestl, AC Immune. Muscimol was synthesized in-house. ${ }^{13}$ Structures are given in Fig. 1.

\subsection{Cell culturing}

IMR-32 cells were cultured in Roswell Park Memorial Institute (RPMI) 1640 medium (Invitrogen, Paisley, UK). The growth medium contained $10 \%$ fetal bovine serum (FBS), penicillin (100 units per $\mathrm{mL}$ ) and streptomycin (100 $\mu \mathrm{g}$ $\mathrm{mL}^{-1}$ ), all from Invitrogen. Cells were kept at $37^{\circ} \mathrm{C}$ in a humidified atmosphere with $5 \% \mathrm{CO}_{2}$.

\subsection{Epic DMR assay}

The day before the assay, IMR-32 cells were seeded into an Epic 384-well fibronectin-coated glass microplate (Corning, New York, NY, USA) at a density of 15000 cells per well. The plate was left for 30 minutes at room temperature and then incubated at $37{ }^{\circ} \mathrm{C}$ in a humidified atmosphere with $5 \% \mathrm{CO}_{2}$ overnight (approximately 18 hours). On the day of assay, growth media was removed, and cells were washed three times with assay buffer (Hank's Balanced Salt Solution (HBSS) supplemented with $20 \mathrm{mM}$ 4-(2-hydroxyethyl)piperazine-1-ethanesulfonic acid (HEPES), $1 \mathrm{mM} \mathrm{CaCl}_{2}$ and 1 $\mathrm{mM} \mathrm{MgCl}_{2}, \mathrm{pH}$ 7.4) using a 24-channel wand suction device (for 384 well format) (V\&P Scientific, Inc., San Diego, CA, USA). Cells were then allowed to equilibrate in assay buffer for 1-2 hours at room temperature in the Epic Benchtop System (Corning) until the change during the last 2.5 minutes was less than $5 \mathrm{pm}$. Up to $0.5 \%$ dimethylsulfoxide (DMSO) was added to the buffer if the compound was dissolved in this solvent to avoid variation in buffer composition upon addition of compound. The assay was initiated with 5 minutes of baseline recording after which compounds were added. In experiments with antagonists, GABA was added 10 minutes after application of the antagonist. DMR signals were recorded for 2-3 hours, and data analyzed and exported with the Epic Analyzer Software (Corning). All DMR signals were background corrected.

\subsection{RNA extraction, reverse transcription and quantitative PCR (qPCR)}

IMR-32 cells were grown to approximately $90 \%$ confluency in $10 \mathrm{~cm}$ dishes. After discarding the cell media, cells were washed once in phosphate-buffered saline (PBS) (Invitrogen) and total RNA extracted using PureLink® RNA mini kit from Ambion (Thermo Fisher Scientific, Waltham, MA, USA) and following treated with DNAse using Turbo DNA-free kit (Ambion), all according to the manufacturer's protocol. The<smiles>COc1ccc(-c2ccc(=N)n(CCCC(=O)O)n2)cc1</smiles>

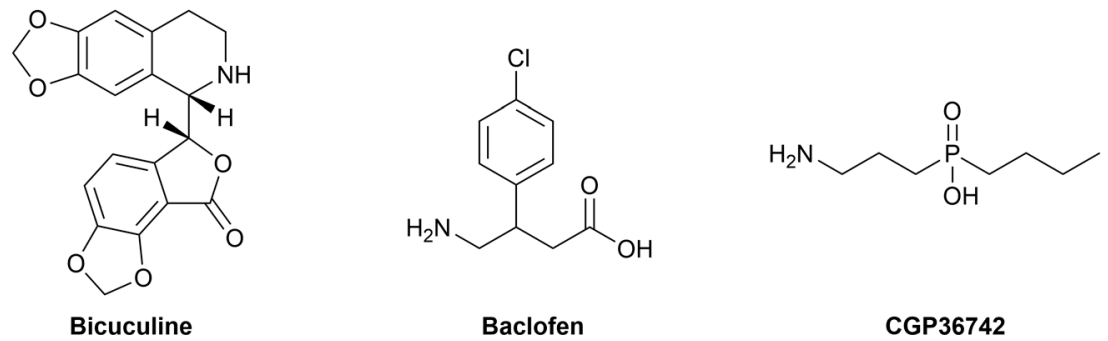

Fig. 1 Structures of compounds used to study $\mathrm{GABA}_{A}$ receptor pharmacology in IMR-32 neuroblastoma cells. 
A

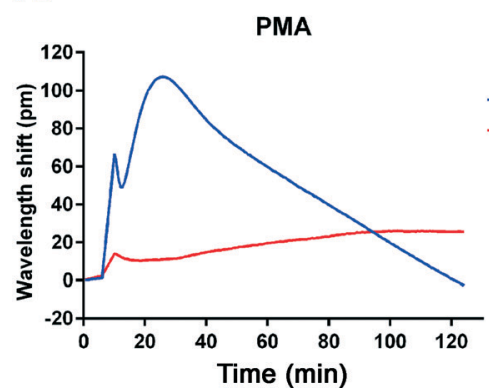

B

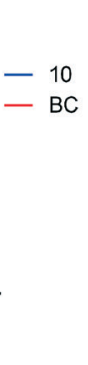

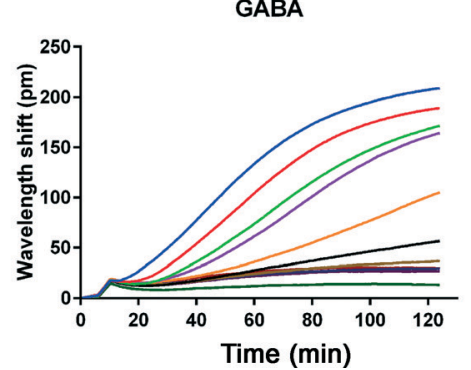

C

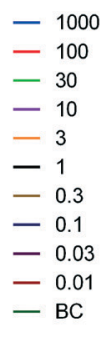

GABA

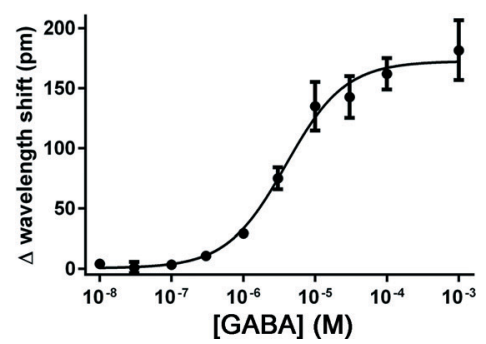

Fig. 2 Ligand-induced DMR signals measured in IMR-32 cells. Kinetic traces after application of the PKC activator, PMA (10 $\mu M)(A)$ and increasing concentrations of GABA as a function of time (concentrations given in $\mu \mathrm{M}$ ) (B). Results are shown as means of quadruplicate (A) or triplicate (B) measurements from a single representative experiment. At least four additional experiments gave similar results. GABA responses from (B) at 120 minutes plotted against increasing concentrations of GABA (C). Results are shown as means \pm standard deviations of triplicate measurements. The derived $\mathrm{EC}_{50}$ value for GABA is stated in Table 1. BC, buffer control.

reverse transcription was performed using qScript ${ }^{\mathrm{TM}}$ cDNA SuperMix (Quanta Biosciences, Gaithersburg, MD, USA) on a standard PCR machine $\left(25^{\circ} \mathrm{C}\right.$ for $5 \mathrm{~min}, 42{ }^{\circ} \mathrm{C}$ for $30 \mathrm{~min}, 85$ ${ }^{\circ} \mathrm{C}$ for $5 \mathrm{~min}$ ) and cDNA stored at $-20{ }^{\circ} \mathrm{C}$ until further processing.

qPCR was performed in 96-well plates (Agilent Technologies, Santa Clara, CA, USA) mixing PerfeCTa SYBR Green FastMix (Quanta Biosciences), nuclease free water (Qiagen, West Sussex, UK), and primers (TAG Copenhagen A/S (Copenhagen, Denmark). The PCR was performed with an initial denaturation step of $95{ }^{\circ} \mathrm{C}$ for $30 \mathrm{~s}$, followed by 40 cycles of 5 $\mathrm{s}$ at $95{ }^{\circ} \mathrm{C}, 60^{\circ} \mathrm{C}$ for 15 seconds and $72{ }^{\circ} \mathrm{C}$ for $10 \mathrm{~s}$. To assure single-product amplification, a dissociation curve analysis was performed consisting of $60 \mathrm{~s}$ at $95{ }^{\circ} \mathrm{C}, 30 \mathrm{~s}$ at $55{ }^{\circ} \mathrm{C}$ and $30 \mathrm{~s}$ at $95{ }^{\circ} \mathrm{C}$. The qPCR was performed using the Agilent Mx3005P qPCR system (Agilent Technologies), and the corresponding MxPro software was used to determine the Ct values. The $\Delta \mathrm{Ct}$ values were calculated using $2^{\text {(reference } \mathrm{Ct} \text {-target } \mathrm{Ct} \text { ) }}$ according to Schmittgen \& Livak. ${ }^{14}$

\subsection{Data analysis}

Data and statistical analysis were performed in GraphPad Prism 6 (GraphPad Software, San Diego, CA, USA), and agonist curves were fitted by nonlinear regression using the equation for sigmoidal concentration-response with variable slope:

Table $1 \quad \mathrm{EC}_{50}$ and $\mathrm{IC}_{50}$ values for $\mathrm{GABA}_{\mathrm{A}}$ receptor agonists and antagonists in IMR-32 cells in the label-free Epic assay. Values are derived from fitted concentration-response curves and are based on at least three independent experiments for each compound $(n)$

\begin{tabular}{lll}
\hline Agonists & $\mathrm{EC}_{50}(\mu \mathrm{M})$ & $\mathrm{pEC}_{50} \pm \mathrm{SEM}$ \\
\hline GABA & 2.94 & $5.58 \pm 0.10(n=5)$ \\
Muscimol & 2.04 & $5.77 \pm 0.14(n=4)$ \\
\hline Antagonists & $\mathrm{IC}_{50}(\mu \mathrm{M})$ & $\mathrm{pIC}_{50} \pm \mathrm{SEM}$ \\
\hline Bicuculline & 16.7 & $4.80 \pm 0.092(n=3)$ \\
Gabazine & 7.38 & $5.34 \pm 0.29(n=3)$
\end{tabular}

$$
Y=\text { Bottom }+\frac{(\text { Top }- \text { Bottom })}{1+10^{\left(\log \mathrm{EC}_{50}-X\right) \times \text { HillSlope }}}
$$

Here, $Y$ is the response, $X$ is the logarithm of the concentration, Top and Bottom are the plateaus in the same unit as $Y, \mathrm{EC}_{50}$ is the concentration that gives a response halfway between Bottom and Top, and the Hillslope describes the steepness of the curve.

Similarly, inhibitory curves were fitted by nonlinear regression using the variable slope model:

$$
Y=\text { Bottom }+\frac{(\text { Top }- \text { Bottom })}{1+10^{\left(\log \mathrm{IC}_{50}-X\right) \times \text { Hillslope }}}
$$

Here, $\mathrm{IC}_{50}$ is the concentration that results in a response halfway between Top and Bottom.

\section{Results and discussion}

\subsection{Effects of GABA on IMR-32 cells in the Epic DMR assay}

The human neuroblastoma cell line IMR-32 has previously been reported to express functional $\mathrm{GABA}_{\mathrm{A}}$ receptors. ${ }^{15}$ As our laboratory is generally interested in $\mathrm{GABA}_{\mathrm{A}}$ receptors as pharmacological targets and in identifying novel ligands for these, we wished to investigate the possibility of studying endogenous $\mathrm{GABA}_{\mathrm{A}}$ receptor signals by means of the labelfree DMR technology. The technology has the further advantage that ligands with novel mechanisms of action may be identified. In contrast to traditional electrophysiological methods that focus on the flux of ions across the membrane, the label-free technique measures overall cellular responses and may therefore reveal novel interactions between the ion channel and e.g. its effectors. ${ }^{16}$

IMR-32 cells were plated in 384-well fibronectin-coated Epic plates approximately 16-20 hours before the assay. To confirm that cells were viable and to confirm assay functionality, we used the compound PMA (a PKC activator) as a positive control. ${ }^{17}$ As illustrated in Fig. 2A, a $10 \mu \mathrm{M}$ concentration 

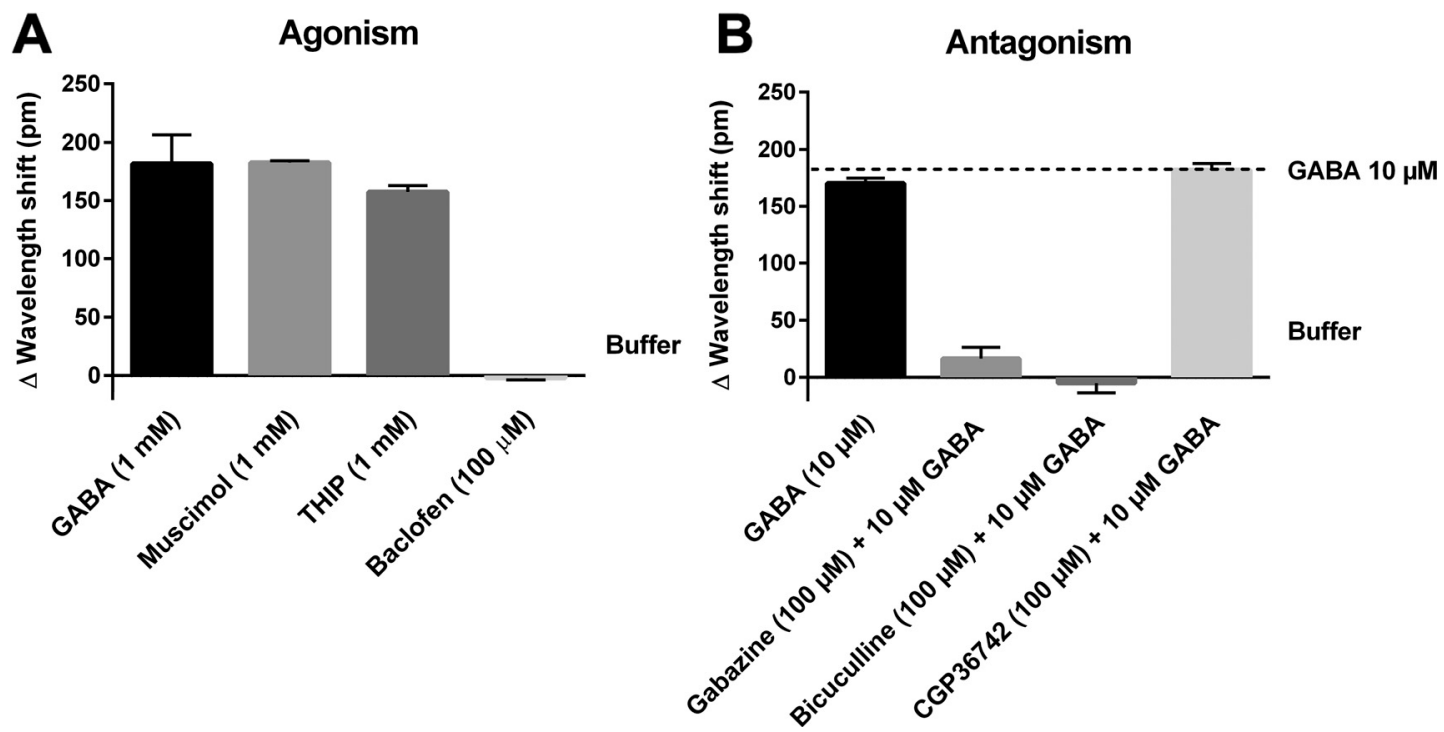

Fig. 3 Validation of $G A B A_{A}$ receptor signals in IMR-32 cells. DMR responses to GABA $A_{A}$ and $G A B A_{B}$ receptor agonists at $1 \mathrm{mM}$ or $100 \mu M$ concentrations compared to GABA and buffer levels (A). Effects of $G_{A B A}$ and $G A B A_{B}$ antagonists at $100 \mu M$ concentrations in response to the GABAinduced $\mathrm{EC}_{80}$ concentration $(10 \mu \mathrm{M})(\mathrm{B})$. Results are shown as means \pm standard deviations of triplicate measurements from a single representative experiment (measured at $140 \mathrm{~min}$ ). Two additional experiments gave similar results.

of PMA induced a robust change in DMR (max. 100 pm signal with a peak after approx. $30 \mathrm{~min}$ ). We then turned to measuring GABA-induced responses by applying increasing concentrations (0.01-1000 $\mu \mathrm{M})$ of GABA and recorded for two hours. We observed reproducible and concentrationdependent increases in the DMR kinetic traces that reached plateau after 90-120 min (Fig. 2B). Conversion of the data into sigmoidally shaped concentration-response curves gave a GABA EC $E_{50}$ value of $2.94 \mu \mathrm{M}$ (Fig. 2C, Table 1).

\subsection{Validation of endogenous $\mathrm{GABA}_{\mathrm{A}}$ receptor signals in IMR-32 cells using the Epic DMR assay}

To confirm that the GABA-induced DMR signals in IMR-32 cells stem from $\mathrm{GABA}_{\mathrm{A}}$ receptors and not other GABAergic targets, e.g. metabotropic $\mathrm{GABA}_{\mathrm{B}}$ receptors, we tested several reference compounds known to be selective for $\mathrm{GABA}_{\mathrm{A}}$ and $\mathrm{GABA}_{\mathrm{B}}$ receptors. Initially, this was performed using single concentrations (0.1-1 mM) of the $\mathrm{GABA}_{\mathrm{A}}$ agonists muscimol and THIP, and the $\mathrm{GABA}_{\mathrm{B}}$ agonist baclofen (for structures, see Fig. 1). As would be expected for $G_{A B A}$-mediated responses, we observed a large increase in the DMR responses to muscimol and THIP, whereas no effect was seen with baclofen (Fig. 3A). The kinetic profiles of muscimol and THIP had the same shape and time course as GABA (Fig. 2B). Correspondingly, we found that the two $\mathrm{GABA}_{\mathrm{A}}$ antagonists, gabazine and bicuculline, but not the $\mathrm{GABA}_{\mathrm{B}}$ antagonist, CGP36742, ${ }^{18}$ were able to inhibit the GABA EC Eo signal (Fig. 3B). In addition, no effect of the antagonists were seen when applied alone (Fig. S1†), demonstrating that no nonspecific effects occur at these concentrations. Furthermore, it indicates that the receptors are not constitutively active. The single-concentration determinations verified that $\mathrm{GABA}_{\mathrm{A}}$ receptors are responsible for the DMR signals measured in IMR-32 cells. To further characterize the pharmacology of the employed GABA $_{A}$ ligands, we made full concentration-response curves. The kinetic traces and corresponding concentrationresponse curves are shown in Fig. 4, with the obtained potencies collected in Table 1 . The DMR signals could be directly transformed into a sigmoidal concentration-response curve for muscimol (Fig. 4A and B), revealing an $\mathrm{EC}_{50}$ value of $2.04 \mu \mathrm{M}$ (Table 1). Likewise, using $10 \mu \mathrm{M}$ of GABA, corresponding to $\mathrm{EC}_{80}$, gabazine and bicuculline concentration-dependently inhibited the response (Fig. 4C and E) and yielded $\mathrm{IC}_{50}$ values of 7.38 and $16.7 \mu \mathrm{M}$, respectively (Fig. 4D and F; Table 1). For this evaluation we used the late responses (typically $140 \mathrm{~min}$ ) for quantification. We also noted some smaller peak effects (10-30 pm) after 10-20 min, which were, however very small and not as consistent. In an earlier study, IMR-32 was also shown to be activated by GABA and muscimol in a chloride efflux assay, while baclofen showed no effect, ${ }^{19}$ underlining the presence of functional $\mathrm{GABA}_{\mathrm{A}}$ receptors in this cell line.

An attribute of DMR label-free assays, which distinguishes them from other cell-based assays, is that they generate a kinetic profile of a given compound. In the current study, we obtained similar-looking kinetic profiles for the tested $\mathrm{GABA}_{\mathrm{A}}$ agonists. These developed quite slowly and saturated only after 120-180 min (Fig. 2 and 4). This indicates that, in IMR32 cells, these ligands all act at the same target, triggering similar intracellular events. The slowly developing DMR kinetic traces obtained for $\mathrm{GABA}_{\mathrm{A}}$ receptor agonists in the IMR-32 cells suggest that down-stream cellular effects are taking place after ion channel activation. It highlights the potential of DMR assays to identify signaling pathways induced by ion channel activation that would never be observed in traditional electrophysiological measurements of ion flux. 


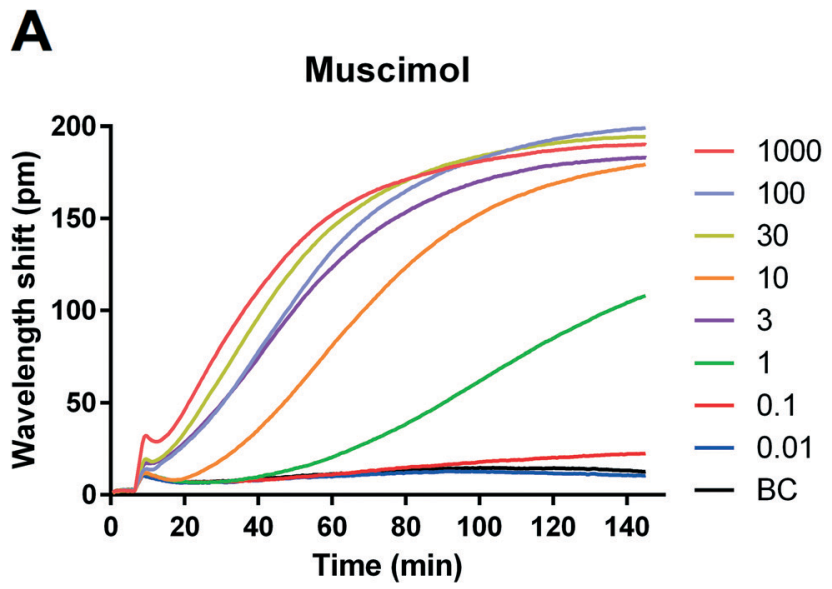

B

C

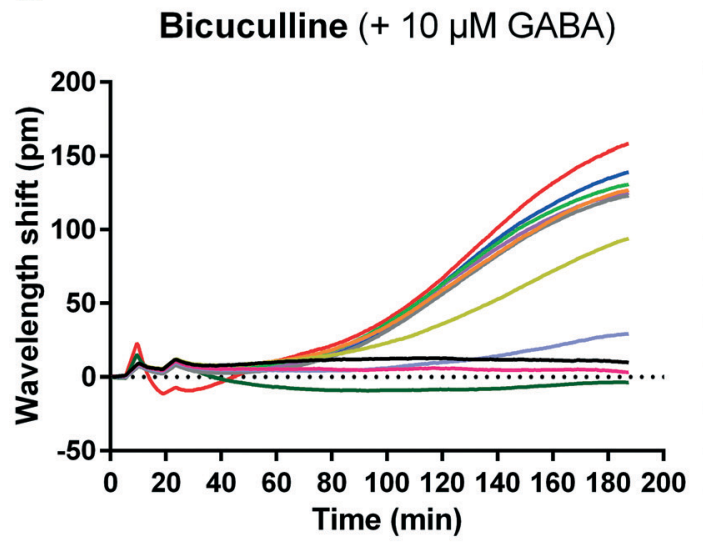

E

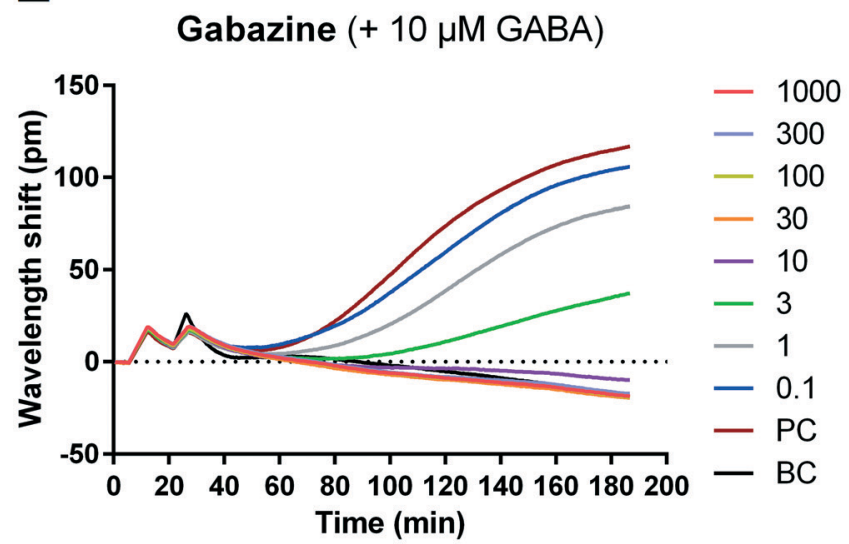

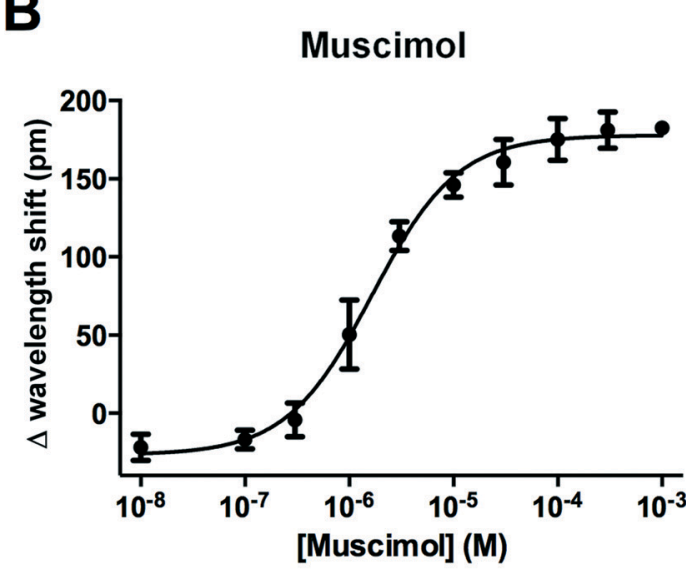

D

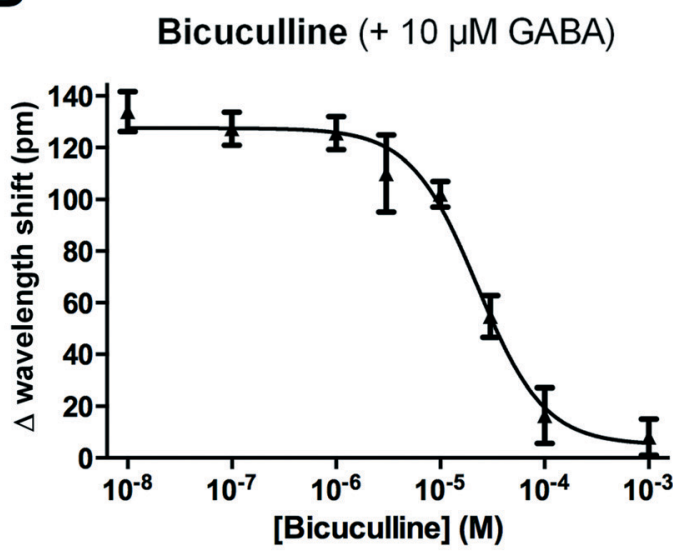

$\mathbf{F}$

Gabazine (+ $10 \mu \mathrm{M}$ GABA)

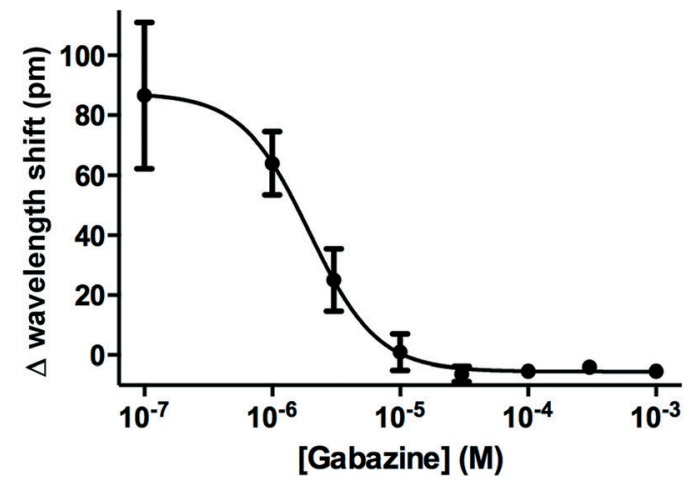

Fig. 4 DMR kinetic traces and concentration-response curves of selected $G A B A_{A}$ receptor ligands in IMR-32 cells. Kinetic traces after application of the agonist muscimol as a function of time (concentrations given as $\mu \mathrm{M}$ ) (A). Muscimol responses from (A) at 140 minutes plotted against increasing concentrations of muscimol (B). Kinetic traces after application of increasing concentrations of the antagonists bicuculline (C) and gabazine (E) together with a fixed concentration of $10 \mu \mathrm{M}$ of $\mathrm{GABA}\left(\sim \mathrm{EC}_{80}\right)$ as a function of time (concentrations given in $\left.\mu \mathrm{M}\right)$. Antagonist responses from (C) and (E) at 140 minutes plotted against increasing antagonist concentrations (D) and (F), respectively. All results are shown as means of triplicate measurements from a single representative experiment. Derived $\mathrm{EC}_{50}$ and $\mathrm{IC}_{50}$ values are listed in Table 1. BC, buffer control. $\mathrm{PC}$, positive control ( $=10 \mu \mathrm{M}$ GABA, corresponding to $\mathrm{EC}_{80}$ ).

Importantly, as reported for several GPCRs, the kinetic profile may be highly dependent on cellular context and should be interpreted with care. ${ }^{7}$ For comparison, a Corning technical report on recombinant $\alpha_{1} \beta_{2} \gamma_{2}$ GABA $_{A}$ receptors in Wss- 1 cells shows quite a different kinetic profile with a GABA-induced peak after approx. $10-20 \mathrm{~min} .^{20}$ Whether it will be possible to obtain a "profile signature" of $\mathrm{GABA}_{\mathrm{A}}$ ligands used to group subtype-specific ligands requires further studies. 
Table 2 qPCR primer sequences used to analyze $\mathrm{GABA}_{\mathrm{A}}$ receptor subunits in the human neuroblastoma cell line, IMR-32. The reference gene was B2M (beta-2 microglobulin)

\begin{tabular}{|c|c|c|}
\hline Target & Primers & Amplicon size \\
\hline \multirow[t]{2}{*}{$\alpha_{1}$} & F: GGATTGGGAGAGCGTGTAACC & 66 \\
\hline & R: TGAAACGGGTCCGAAACTG & \\
\hline \multirow[t]{2}{*}{$\alpha_{2}$} & F: GTTCAAGCTGAATGCCCAAT & 160 \\
\hline & R: ACCTAGAGCCATCAGGAGCA & \\
\hline \multirow[t]{2}{*}{$\alpha_{3}$} & F: CAACTTGTTTCAGTTCATTCATCCTT & 102 \\
\hline & R: CTTGTTTGTGTGATTATCATCTTCTTAGG & \\
\hline \multirow[t]{2}{*}{$\alpha_{4}$} & F: CATGACCACACTAAGCATCAGT & 118 \\
\hline & R: AAACTCGATAAGGGCCGAAAAT & \\
\hline \multirow[t]{2}{*}{$\alpha_{5}$} & F: CTTCTCGGCGCTGATAGAGT & 105 \\
\hline & R: CGC TTTTTCTTGATCTTGGC & \\
\hline \multirow{2}{*}{$\alpha_{6}$} & F: ACCCACAGTGACAATATCAAAAGC & 67 \\
\hline & R: GGAGTCAGGATGCAAAACAATCT & \\
\hline \multirow[t]{2}{*}{$\beta_{1}$} & F: AGGGTAGCTGACCAACTCTGG & 114 \\
\hline & R: TGTTCCATCAGGATGCAGTCG & \\
\hline \multirow{2}{*}{$\beta_{2}$} & F: GCAGAGTGTCAATGACCCTAGT & 137 \\
\hline & R: TGGCAATGTCAATGTTCATCCC & \\
\hline \multirow[t]{2}{*}{$\beta_{3}$} & F: CCGTTCAAAGAGCGAAAGCAACCG & 105 \\
\hline & R: TCGCCAATGCCGCCTGAGAC & \\
\hline \multirow[t]{2}{*}{$\gamma_{1}$} & F: CCTTTTCTTCTGCGGAGTCAA & 91 \\
\hline & R: CATCTGCCTTATCAACACAGTTTCC & \\
\hline \multirow[t]{2}{*}{$\gamma_{2}$} & F: CACAGAAAATGACGGTGTGG & 136 \\
\hline & R: TCACCCTCAGGAACTTTTGG & \\
\hline \multirow[t]{2}{*}{$\gamma_{3}$} & F: TCCTTTACACTTTGAGGCTCAC & 176 \\
\hline & R: CCGCCATGATTTCTGGTCAG & \\
\hline \multirow[t]{2}{*}{$\delta$} & F: CAATCCTACATGCCCTCCGT & 186 \\
\hline & R: GAAGTAGACGTCCAGTGCCT & \\
\hline \multirow[t]{2}{*}{$\varepsilon$} & F: TGGATTCTCACTCTTGCCCTCTA & 107 \\
\hline & R: GGAGTTCTTCTCATTGATTTCAAGCT & \\
\hline \multirow[t]{2}{*}{$\pi$} & F: CAATTTTGGTGGAGAACCCG & 110 \\
\hline & R: GCTGTCGGAGGTATATGGTG & \\
\hline \multirow[t]{2}{*}{$\theta$} & F: CCAGGGTGACAATTGGCTTAA & 63 \\
\hline & R: CCCGCAGATGTGAGTCGAT & \\
\hline \multirow[t]{2}{*}{$\rho_{1}$} & F: TTATTTCCCCGCTACCCTGAT & 101 \\
\hline & R: GCACCGTTGTGATACCTAAGG & \\
\hline \multirow[t]{2}{*}{$\rho_{2}$} & F: TACAGCATGAGGATTACGGT & 81 \\
\hline & R: CAAAGAACAGGTCTGGGAG & \\
\hline \multirow[t]{2}{*}{$\rho_{3}$} & F: TGATGCTTTCATGGGTTTCA & 111 \\
\hline & R: CGCTCACAGCAGTGATGATT & \\
\hline \multirow[t]{2}{*}{$\mathrm{B} 2 \mathrm{M}$} & F: CCTGCCGTGTGAACCATGTGACT & 94 \\
\hline & R: GCGGCATCTTCAAACCTCCATGATG & \\
\hline
\end{tabular}

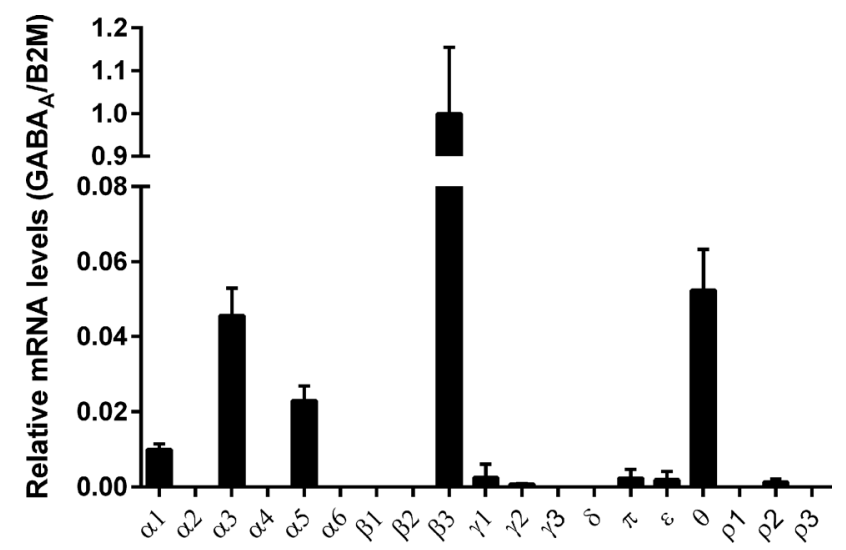

Fig. 5 Relative $\mathrm{GABA}_{A}$ receptor subunit mRNA levels in IMR-32 neuroblastoma cells related to the reference gene, beta-2 microglobulin (B2M). Results are shown as means \pm standard deviations of triplicate measurements from a single representative experiment. Additional experiments gave similar results.
The only other ligand-gated ion channel, reported to date using the label-free technology based on DMR, is the $\mathrm{K}_{\mathrm{ATP}}$ channel endogenously expressed in C2A cells,${ }^{21}$ thus in general there is little basis for comparison to our current findings.

\subsection{Quantitative PCR analysis of $\mathrm{GABA}_{\mathrm{A}}$ receptor subunits in IMR-32 cells}

To investigate the relative expression levels of all $19 \mathrm{GABA}_{\mathrm{A}}$ receptor subtypes in IMR-32 cells, qPCR was carried out. To this end, we measured mRNA levels of the $\mathrm{GABA}_{\mathrm{A}}$ subunits $\alpha_{1-6}, \beta_{1-3}, \gamma_{1-3}, \delta, \pi, \theta, \varepsilon$ and $\rho_{1-3}$ using specific primers (Table 2). The $\mathrm{GABA}_{\mathrm{A}}$ subunit displaying the relatively highest expression was the $\beta_{3}$ subunit, while $\alpha_{3}, \alpha_{5}$ and $\theta$ were found to be expressed at 14-33 times lower levels in comparison, but still significantly higher than very low-expressing subunits such as $\gamma_{1-3}$ and $\delta$ (Fig. 5). The relatively high abundance of $\beta_{3}, \alpha_{3}, \alpha_{5}$ and $\theta$ mRNA levels suggests that functional receptors containing these subunits are responsible for the obtained DMR signals in IMR-32 cells. As $\beta_{3}$ is reported to form functional binary and tertiary receptors with either $\alpha_{3} / \alpha_{5}$, or $\alpha_{3 / 5}$ and $\theta$ subunits in Xenopus oocytes, ${ }^{22,23}$ it remains unknown which subtype is predominating in IMR-32 cells under the conditions of the assay. The obtained $\mathrm{EC}_{50}$ value for GABA of $2.91 \mu \mathrm{M}$ also makes it impossible to discriminate between subtypes, as reported values are quite similar (i.e. $4.5 \mu \mathrm{M}$ for $\alpha_{3} \beta_{3}$ and $3.4 \mu \mathrm{M}$ for $\alpha_{3} \beta_{3} \theta$, measured in oocytes)..$^{22}$

Previous reports demonstrate functional $\mathrm{GABA}_{\mathrm{A}}$ responses in IMR-32 cells, ${ }^{15,24}$ but the exact subunit combinations are not obvious. Although some studies have presented receptor combinations containing the benzodiazepine site (e.g. $\left.\alpha_{5} \beta_{3} \gamma_{2}\right),{ }^{25}$ others were unable to show any functional benzodiazepine responses. ${ }^{19}$ In agreement with these reports is the much higher level of the $\beta_{3}$ subunit in this study. Interestingly, the expression of the $\theta$ subunit in IMR-32 cells to significant levels has not been reported before. Future studies using subtype-specific tool compounds and ideally complemented with knock-down studies may be used to reveal the subtype(s) predominantly responsible for the IMR$32 \mathrm{GABA}_{\mathrm{A}}$-mediated responses and/or the specific pharmacological role of the $\theta$ subunit.

\section{Conclusions}

As exemplified here, the DMR label-free assay is an attractive assay method for performing quantitative pharmacology of $\mathrm{GABA}_{\mathrm{A}}$ receptors. The method may thus prove useful for other ligand-gated ion channels or other non-GPCR targets. Compared to more traditional assays, it gives an informationrich read-out in real-time that correlates to all cellular events. The data from the current study specifically demonstrate the applicability of the label-free assay on endogenously expressed $\mathrm{GABA}_{\mathrm{A}}$ receptors in IMR-32 neuroblastoma cells. It provides a potential useful alternative assay with a much higher throughput for pharmacological testing in the search 
for novel $\mathrm{GABA}_{\mathrm{A}}$ receptor ligands, carried out in a convenient 384-well format. Being label-free, the use of e.g. fluorescent labels is avoided, which also extends the application of this technology to fluorescent compound testing.

\section{Acknowledgements}

This work was supported by the Lundbeck Foundation (grant R133-A12270), the Danish Research Council, The Aase \& Ejnar Danielsen Foundation, The Hørslev Foundation, The Augustinus Foundation and The Carlsberg Foundation. A thank to Prof. Sven Påhlman, University of Lund for the IMR32 cells and to Trine Lind Devantier (Novo Nordisk) for providing the 24-pin suction device.

\section{References}

1 M. Farrant and Z. Nusser, Nat. Rev. Neurosci., 2005, 6, 215-229.

2 T. I. Saari, M. Uusi-Oukari, J. Ahonen and K. T. Olkkola, Pharmacol. Rev., 2011, 63, 243-267.

3 U. Rudolph and F. Knoflach, Nat. Rev. Drug Discovery, 2011, 10, 685-697.

4 E. Sigel and M. E. Steinmann, J. Biol. Chem., 2012, 287, 40224-40231.

5 M. F. Peters, F. Vaillancourt, M. Heroux, M. Valiquette and C. W. Scott, Assay Drug Dev. Technol., 2010, 8, 219-227.

6 Y. Fang, Expert Opin. Drug Discovery, 2011, 6, 1285-1298.

7 R. Schröder, J. Schmidt, S. Blättermann, L. Peters, N. Janssen, M. Grundmann, W. Seemann, D. Kaufel, N. Merten, C. Drewke, J. Gomeza, G. Milligan, K. Mohr and E. Kostenis, Nat. Protoc., 2011, 6, 1748-1760.

8 M. Grundmann and E. Kostenis, Methods Mol. Biol., 2015, 1272, 199-213.

9 R. Schröder, N. Janssen, J. Schmidt, A. Kebig, N. Merten, S. Hennen, A. Muller, S. Blättermann, M. Mohr-Andra, S. Zahn, J. Wenzel, N. J. Smith, J. Gomeza, C. Drewke, G. Milligan, K. Mohr and E. Kostenis, Nat. Biotechnol., 2010, 28, 943-949.
10 S. Pai, F. Verrier, H. Sun, H. Hu, A. M. Ferrie, A. Eshraghi and Y. Fang, J. Biomol. Screening, 2012, 17, 1180-1191.

11 S. Hennen, H. Wang, L. Peters, N. Merten, K. Simon, A. Spinrath, S. Blättermann, R. Akkari, R. Schrage, R. Schröder, D. Schulz, C. Vermeiren, K. Zimmermann, S. Kehraus, C. Drewke, A. Pfeifer, G. M. Konig, K. Mohr, M. Gillard, C. E. Müller, Q. R. Lu, J. Gomeza and E. Kostenis, Sci. Signaling, 2013, 6, ra93, DOI: 10.1126/scisignal.2004350.

12 M. R. Fleming and L. K. Kaczmarek, J. Recept. Signal Transduction Res., 2009, 29, 173-181.

13 P. Krogsgaard-Larsen and S. B. Christensen, Acta Chem. Scand., Ser. B, 1976, 30, 281-282.

14 T. D. Schmittgen and K. J. Livak, Nat. Protoc., 2008, 3, 1101-1108.

15 D. W. Sapp and H. H. Yeh, J. Neurosci. Res., 2000, 60, 504-510.

16 J. Comley, Drug Discov. World, 2011, 45-62.

17 W. S. Liu and C. A. Heckman, Cell. Signalling, 1998, 10, 529-542.

18 W. Froestl, S. J. Mickel, R. G. Hall, G. von Sprecher, D. Strub, P. A. Baumann, F. Brugger, C. Gentsch, J. Jaekel and H. R. Olpe, et al., J. Med. Chem., 1995, 38, 3297-3312.

19 S. M. Anderson, R. J. De Souza and A. J. Cross, Neuropharmacology, 1993, 32, 455-460.

20 D. H. Randle and A. Gao, Label-free ion channel assays using the Corning Epic system, Corning techical report: (http://www. corning.com/media/worldwide/cls/documents/snappshots_ 156_labelfree_ion_channel_assays_epic_system.pdf).

21 H. Sun, Y. Wei, H. Deng, Q. Xiong, M. Li, J. Lahiri and Y. Fang, Sci. Rep., 2014, 4, 4934.

22 M. Mortensen, B. Patel and T. G. Smart, Front. Cell. Neurosci., 2011, 6, 1.

23 N. Karim, P. Wellendorph, N. Absalom, G. A. Johnston, J. R. Hanrahan and M. Chebib, Amino Acids, 2013, 44, 1139-1149.

24 X. Zhou and S. S. Smith, Neuropharmacology, 2009, 56, 1041-1053.

25 F. Wang, Z. Xu, C. T. Yuen, C. Y. Chow, Y. L. Lui, S. Y. Tsang and H. Xue, Neuropharmacology, 2007, 53, 574-582. 